\title{
KAJIAN EMPIRIS KEBIJAKAN HUTANG PADA PERUSAHAAN MANUFAKTUR DI BEI
}

\author{
Muhammad Fahmi \\ Rahmawati Hanny Yustrianthe \\ Sekolah Tinggi Ilmu Ekonomi Y.A.I. \\ rahmahanny@gmail.com
}

\begin{abstract}
This study aimed to analyze the factors that affect the debt policy on companies listed in Indonesia Stock Exchange in the year 2011-2013. The sampling technique is done by using purposive sampling. The sample in this study as many as 34 companies listed in Indonesia Stock Exchange. Data analysis began with descriptive statistical test, followed by the normality of the data, the classical assumption test, and regression analysis.The results of this study indicate that partial insider ownership structure, a set of investment opportunity, asset structure, and free cash flow do not affect debt policy. Only the size of the company and partially affecting profitability debt policy. Insider ownership structure, a set of investment opportunity, asset structure, the size of the company, free cash flow and profitability simultaneously affect the debt policy.
\end{abstract}

Keywords: Insider Ownership Structure, A Set of Investment Opportunities, Asset Structure, The Size of The Company, Free Cash Flow, Profitability, Debt Policy.

\section{PENDAHULUAN}

Laporan keuangan merupakan media komunikasi antara manajemen perusahaan dan investor mengenai gambaran keuangan perusahaan. Laporan keuangan juga menunjukkan hasil pertanggung jawaban manajemen atas penggunaan sumber daya yang dipercayakan kepada mereka. Informasi dalam laporan keuangan harus disajikan secara benar dan jujur dengan mengungkap fakta sebenarnya yang menjadi kepentingan banyak pihak. Dengan demikian, laporan keuangan dituntut untuk disajikan dengan integritas yang tinggi.

Salah satu unsur laporan keuangan adalah hutang. Hutang didefinisikan oleh FASB dalam Ikhsan dan Suprasto (2008:178) sebagai
\end{abstract}

pengorbanan manfaat ekonomi dimasa yang akan datang yang muncul dari kewajiban khusus suatu badan usaha untuk mentransfer aktiva atau menyediakan jasa pada badan usaha lain dimasa yang akan datang sebagai akibat transaksi atau kejadian di masa lalu. Hutang juga merupakan salah satu sumber pembiayaan eksternal yang digunakan oleh perusahaan untuk membiayai kebutuhan pendananya.

Untuk dapat bersaing dengan perusahaanperusahaan lainnya, suatu perusahaan dihadapkan pada kondisi yang mendorong mereka untuk lebih kreatif dalam memperoleh sumber pendanaan yang paling efektif. Keputusan pendanaan perusahaan merupakan salah satu keputusan penting bagi perusahaan karena hal ini juga memiliki pengaruh terhadap resiko 
perusahaan dan keputusan pemberian kredit oleh pihak perbankan. Hutang perusahaan berkaitan sangat erat dengan struktur modal suatu perusahaan. Banyak faktor yang memengaruhi keputusan perusahaan dalam melakukan pendanaan diantaranya komposisi struktur modal perusahaan. Komposisi tersebut yang didalamnya terdapat kepemilikan manajerial tentu akan memengaruhi keputusan pendanaan yang dilakukan perusahaan. Pengambilan kebijakan tersebut sangat erat kaitannya dengan keputusan yang diambil oleh manajemen perusahaan yang sangat pekat dengan masalah keagenan (agency theory). Dalam teori ini dikenal dua macam biaya keagenan yaitu agency cost of debt dan agency cost of equity. Beban biaya keagenan yang terjadi disisi pemegang saham disebut agency cost of equity, sedangkan biaya keagenan yang timbul akibat penggunaan hutang perusahaan disebut agency cost of debt. Sehubungan dengan hutang, dapat dikatakan bahwa semakin tinggi proporsi hutang, maka resiko kebangkrutan akan semakin meningkat, sehingga debtholder memerlukan tambahan return untuk menutupi tambahan resiko yang terjadi. Dengan kata lain, hutang digunakan untuk membagi "beban" biaya keagenan dari pemegang saham kepada debtholder, sehingga agency cost of equity menjadi menurun namun terjadi kenaikan pada sisi agency cost of debt. Jadi pengambilan keputusan hutang akan memengaruhi biaya keagenan yang dikendalikan melalui mekanisme hutang (Steven dan Lina, 2011).

Banyak faktor yang memengaruhi kebijakan hutang berdasarakan pada penelitian terdahulu, diantaranya adalah penelitian yang dilakukan oleh Indahningrum dan Handayani (2009), Karinaputri dan Sofian (2012), Margaretha dan Asmariani (2009), Steven dan Lina (2011), Surya dan Rahayuningsih (2012), Susanto (2011), Susilawati, Agustina dan Tin (2012), Wahidahwati (2002), Yeniatie dan
Destriana (2010). Salah satu faktornya adalah struktur insider ownership. Struktur insider ownership adalah tingkat kepemilikan saham pihak manajemen yang secara aktif ikut dalam pengambilan keputusan, misalnya adalah direktur dan dewan komisaris. Struktur insider ownership dapat diukur dengan proporsi saham yang dimiliki perusahaan pada akhir tahun dan dinyatakan dalam persentase. Semakin besar proporsi kepemilikan manajemen dalam perusahaan maka manajemen akan berusaha lebih giat untuk kepentingan pemegang saham yang notabenenya adalah mereka sendiri (Wahidahwati, 2002). Hasil penelitian yang dilakukan oleh Susilawati, Agustina dan Tin (2012), Wahidahwati (2002) menjelaskan bahwa struktur insider ownership tidak memiliki pengaruh terhadap kebijakan hutang. .Namun hasil penelitian yang dilakukan oleh Susanto (2011) menjelaskan bahwa struktur insider ownership memiliki pengaruh terhadap kebijakan hutang.

Faktor selanjutnya adalah set peluang investasi. Teori investment opportunity set berkaitan dengan keputusan pendanaan yang telah dilakukan perusahaan terdiri dari keputusan pendanaan jangka pendek, menengah dan jangka panjang (Susanto, 2011). Perusahaan yang memiliki set peluang investasi yang tinggi menunjukkan bahwa dana internal perusahaan tersebut lebih dari cukup untuk memenuhi kebutuhan dana perusahaan sehingga dana eksternal tidak diperlukan. Kondisi ini juga sebagai indikator bahwa perusahaan tersebut dapat berkembang dan bagi investor merupakan hal yang menguntungkan karena investasi yang ditanamkan diharapkan bisa memberikan return yang tinggi. Surya dan Rahayuningsih (2012), Susanto (2011) menyatakan bahwa set peluang investasi memiliki pengaruh terhadap kebijakan hutang. Namun penelitian yang dilakukan Steven dan lina (2011) menyatakan bahwa set peluang investasi tidak memiliki pengaruh terhadap kebijakan hutang. 
Struktur aktiva juga merupakan faktor yang diperkirakan memiliki pengaruh terhadap resiko hutang. Menurut Ikhsan dan Suprasto (2008:151-152) Ada tiga definisi aktiva yang dikemukakan oleh para profesional di Amerika Serikat. Definisi pertama adalah sesuatu yang disajikan disaldo debet dan akan dipindahkan setelah tutup buku sesuai dengan prinsip akuntansi (bukan saldo negatif yang akan dinilai sebagai hutang), saldo debet ini merupakan hak milik atau nilai yang didebet atau pengeluaran yang dilakukan untuk mendapatkan kekayaan di masa yang akan datang. Kedua, aktiva adalah sumber ekonomi perusahaan yang diakui dan diukur sesuai dengan prinsip akuntansi berterima umum. Ketiga, aktiva adalah kemungkinan keuntungan ekonomi yang diperoleh atau dikuasai dimasa yang akan datang oleh kesatuan tertentu sebagai akibat atau kejadian yang telah lalu. Aktiva dikelompokan menjadi dua yaitu aktiva lancar dan aktiva tetap. Aktiva tetap memiiliki pengaruh terhadap kebijakan hutang, disebabkan karakteristik sunk cost dari aktiva tetap, seperti tanah, gedung dan bangunan sehingga semakin tinggi jumlahnya maka akan semakin tinggi hutang yang dimiliki perusahaan. Hasil penelitian yang dilakukan oleh Margaretha dan Asmariani (2009), Steven dan Lina (2011), Surya dan Rahayuningsih (2012), Susanto (2011), Yeniatie dan Destriana (2010) menyatakan bahwa struktur aktiva memiliki pengaruh terhadap kebijakan hutang.

Menurut Hol dan Wijst (2006) dalam Susilawati, Agustina dan Tin (2012) ukuran perusahaan adalah suatu skala yang dapat diklasifikasikan dalam besar dan kecilnya perusahaan dengan cara total aktiva, log size nilai pasar saham dan stabilitas penjualan. Besar kecilnya suatu perusahaan akan berpengaruh terhadap struktur modal, dengan kata lain semakiin besar perusahaan maka akan semakin besar pula dana yang dibutuhkan perusahaan untuk melakukan investasi dan untuk menunjang kegiatan operasionalnya. Margaretha dan Asmariani (2009), Surya dan Rahayuningsih (2012), Susanto (2011) menyatakan bahwa ukuran perusahaan memiliki pengaruh terhadap kebijakan hutang. Namun Steven dan Lina (2011) menyatakan bahwa ukuran perusahaan tidak memiliki pengaruh terhadap kebijakan hutang.

Menurut Kieso (2011:211-212) free cash flow is the amount of discretionary cash flow a company has. It can use this cash flow to purchase additional investements, retire its debt, purchase treasury shares, or simply add to its liquidity. Dan hasil yang diperoleh dari penelitian yang dilakukan oleh Indahningrum dan Handayani (2009), Susilawati, Agustina dan Tin (2012) menunjukan bahwa free cash flow memiliki pengaruh terhadap kebijakan hutang.

Dan faktor lain yang diduga memengaruhi kebijakan hutang adalah profitabilitas. Profitabilitas merupakan tingkat keuntungan bersih yang mampu dicapai perusahaan pada saat menjalankan operasionalnya (Susilawati, Agustina dan Tin, 2012). Apabila laba perusahaan tinggi, maka pendanaan dari sektor internal akan mencukupi untuk membiayai kebutuhan tersebut. Semakin tinggi profit yang diperoleh perusahaan maka akan semakin kecil penggunaan hutang dalam pendanaan perusahaan. Apabila kebutuhan dana perusahaan belum mencukupi, perusahaan dapat menggunakan hutang. Indahningrum dan Handayani (2009), Karinaputri dan Sofian (2012), Steven dan Lina (2011), Surya dan Rahayuningsih (2012), Susanto (2011), Susilawati, Agustina dan Tin (2012), Yeniatie dan Destriana (2010) menyatakan bahwa terdapat pengaruh antara profitabilitas terhadap kebijakan hutang. Sebaliknya Margaretha dan Asmariani (2009) menyatakan bahwa profitabilitas tidak memiliki pengaruh terhadap kebijakan hutang.

Adanya temuan ketidakkonsistenan diantara hasil penelitian-penelitian sebelumnya, maka penelitian ini berupaya melakukan pengujian kembali sekaligus mengembangkan 
penelitian sebelumnya dengan menggunakan dimensi waktu dan tempat yang berbeda terkait dengan kajian empiris terkait dengan kebijakan hutan perusahaan manufaktur di BEI. Secara eksplisit, penelitian ini berupaya mengkaji secara empirik faktor-faktor yang memengaruhi kebijakan hutang.

\section{REVIEW LITERATUR DAN HIPOTESIS}

\section{Kebijakan Hutang}

Kebijakan hutang perusahaan merupakan kebijakan yang diambil oleh pihak manajemen dalam rangka memperoleh sumber pembiayaan dari pihak ketiga untuk membiayai aktivitas operasional perusahaan. Hal ini berkaitan erat dengan struktur modal yang dipilih perusahaan. Struktur modal adalah perimbangan antara modal asing atau hutang dengan modal sendiri. Kebijakan hutang diukur dengan menggunakan debt ratio yang mencerminkan kemampuan perusahaan dengan menggunakan seluruh kewajibannya yang ditunjuk oleh beberapa bagian modal sendiri yang digunakan untuk membayar hutang. Oleh karena itu, semakin rendah DER (debt to equity ratio), maka semakin tinggi kemampuan perusahaan untuk membayar seluruh kewajibannya. Pada akhirnya peningkatan hutang akan memengaruhi tingkat pendapatan bersih yang tersedia bagi pemegang saham termasuk deviden yang akan diterima.

\section{Stuktur Insider Ownership}

Kepemilikan manajerial atau insider adalah tingkat kepemilikan saham pihak manajemen yang secara aktif ikut dalam pengambilan keputusan, misalnya direktur dan komisaris (Wahidawati, 2002). Kepemilikan manajerial yang semakin meningkat akan membuat manajemen menjadi semakin berhati-hati dalam mengelola kebijakan hutang perusahaan, karena kekayaan pribadi mereka secara tidak langsung berkaitan erat dengan kekayaan yang dimiliki oleh perusa- haan, sehingga penggunaan hutang menjadi lebih kecil atau optimal. Insider perusahaan mempunyai kepentingan yang lebih besar dalam menjamin keberlangsungan hidup perusahaan karena resiko hutang non diversifiable manajemen lebih besar dari public investor (Masdupi, 2005) dalam (Indahningrum dan Handayani, 2009).

\section{Set Peluang Investasi ( A Set Investment of Opportunity)}

Teori investement opportunity set berkaitan dengan keputusan pendanaan yang telah dilakukan oleh perusahaan yang terdiri dari keputusan pendanaan jangka pendek, menengah, dan jangka panjang (Susanto, 2011). Manajemen perusahaan yang memiliki kesempatan investasi besar relatif lebih fleksibel untuk bertindak oportunistik dan sulit diditeksi, karena real option (tidak sebagaimana real estate) sulit diobservasi tanpa informasi dari pihak internal perusahaan. Akibatnya biaya agensi akan meningkat.

\section{Struktur Aktiva}

Struktur aktiva adalah penetuan seberapa besar alokasi dana untuk masingmasing komponen aktiva, baik dalam aktiva lancar maupun aktiva tetap. Dengan kata lain perimbangan atau perbandingan antara aktiva tetap dan total aktiva (Mamduh, 2004) dalam (Susilawati, Agustina dan Tin, 2012). Perusahaan yang aktivanya sesuai untuk dijadikan jaminan kredit cenderung lebih banyak menggunakan banyak hutang (Junaidi, 2005) dalam (Yeniatie dan Destriana, 2010). Pengukuran struktur aktiva dilakukan dengan melakukan suatu perbandingan antara total aktiva tetap dengan total aktiva yang dimiliki perusahaan.

\section{Ukuran perusahaan}

Hol dan Wijst (2006) dalam Susilawati, Agustina dan Tin (2012) menyatakan bahwa ukuran perusahaan adalah suatu skala yang dapat diklasifikasikan dalam besar dan kecilnya perusahaan dengan cara, antara lain dengan total 
aktiva, log size, nilai pasar saham dan stabilitas penjualan. Besar kecilnya suatu perusahaan akan perpengaruh terhadap struktur modal, dengan kata lain semakin besar perusahaan maka akan semakin besar pula dana yang dibutuhkan perusahaan untuk melakukan investasi dan untuk menunjang kegiatan operasionalnya (Susilawati, Agustina dan Tin, 2012).

\section{Free Cash Flow}

Kieso (2011:211-212) menyebutkan bahwa, free cash flow is the amount of discretionary cash flow a company has. It can use this cash flow to purchase additional investements, retire its debt, purchase treasury shares, or simply add to its liquidity. Konsep free cash flow merupakan perluasan dari konsep biaya keagenan ke dalam manajemen struktur modal. Dan juga menunjukan bahwa tekanan pasar akan mendorong manajer untuk mendistribusikan free cash flow kepada pemegang saham.

Free cash flow berbeda dengan laba bersih, setidaknya dalam dua hal yakni semua biaya non kas ditambahkan kembali ke laba bersih untuk mendapatkan aliran kas dari operasi, sehingga memungkinkan besar laba yang dilaporkan lebih rendah dari aliran kas; dan yang kedua free cash flow terhadap ekuitas merupakan aliran kas residual setelah memenuhi pengeluaran modal dan modal kerja yang dibutuhkan, sedangkan laba bersih mencakup keduanya.

\section{Profitabilitas}

Profitabilitas merupakan tingkat keuntungan bersih yang mampu diraih oleh perusahaan pada saat menjalankan operasionalnya. Profitabilitas menggambarkan pendapatan yang dimiliki perusahaan untuk membiayaai investasi. Profitabilitas menunjukan kemampuan dari modal yang diinvestasikan dalam keseluruhan aktiva yang menghasilkan keuntungan bagi investor (Susilawati, Agustina dan Tin, 2012). Dalam rasio profitabilitas ini dapat dikatakan sampai sejauh mana keefektifan dari seluruh manajemen dalam menciptakan keuntungan bagi perusahaan.

\section{Kerangka Pemikiran dan Pengembangan Hipotesis}

Pengaruh Struktur Insider Ownership terhadap Kebijakan Hutang

Struktur insider ownership adalah tingkat kepemilikan saham pihak manajemen yang secara aktif ikut dalam pengambilan keputusan, misalnya adalah direktur dan dewan komisaris (Wahidahwati, 2002). Hubungan kepemilikan manajerial dan kebijakan hutang memiliki hubungan timbal balik, artinya jika terjadi peningkatan persentase kepemilikan manajerial maka akan meningkatkan penggunaan hutang. Dan apabila tingkat kepemilikan manajerial tinggi maka perusahaan cenderung akan mengalokasikan labanya untuk laba ditahan daripada membayar deviden dengan tujuan sumber dana internal lebih efisien dibandingkan dengan sumber dana yang diperoleh dari pihak ekternal. Sedangkan apabila tingkat kepemilikan manajerial rendah, maka perusahaan melakukan pembagian deviden yang besar untuk memberikan tanda yang baik akan kinerja dimasa yang akan datang sehingga hal tersebut akan meningkatkan reputasi perusahaan di hadapan investor. Hal tersebut konsisten dengan hasil penelitian yang dilakukan oleh Susanto (2011) yang menjelaskan bahwa struktur insider ownership memiliki pengaruh terhadap kebijakan hutang.

\section{$\mathrm{H}_{1}$ : Struktur insider ownership berpenga- ruh terhadap kebijakan hutang.}

\section{Pengaruh Set Peluang Investasi terhadap Kebijakan Hutang}

Teori investment opportunity set berkaitan dengan keputusan pendanaan yang telah dilakukan perusahaan terdiri dari keputusan pendanaan jangka pendek, menegah dan jangka panjang (Susanto, 2011). Perusahaan yang memiliki set peluang investasi yang tinggi menunjukan bahwa dana internal perusahaan tersebut lebih dari cukup 
untuk memenuhi kebutuhan dana perusahaan sehingga dana eksternal tidak diperlukan. Kondisi ini juga sebagai indikator bahwa perusahaan tersebut dapat berkembang dan bagi investor merupakan hal yang menguntungkan karena investasi yang ditanamkan diharapkan bisa memberikan return yang tinggi. Hal tersebut konsisten dengan hasil penelitian yang dilakukan oleh Surya dan Rahayuningsih (2012), Susanto (2011) yang menyatakan bahwa set peluang investasi memiliki pengaruh terhadap kebijakan hutang.

\section{$\mathrm{H}_{2}$ : Set peluang investasi berpengaruh terhadap kebijakan hutang}

\section{Pengaruh Struktur Aktiva terhadap Kebija- kan Hutang}

Struktur aktiva adalah penetuan seberapa besar alokasi dana untuk masing-masing komponen aktiva, baik dalam aktiva lancar maupun aktiva tetap. Dengan kata lain perimbangan atau perbandingan antara aktiva tetap dan total aktiva (Mamduh, 2004) dalam (Susilawati, Agustina dan Tin, 2012). Aktiva dikelompokan menjadi dua yaitu aktiva lancar dan aktiva tetap. Aktiva tetap memiiliki pengaruh terhadap kebijakan hutang, disebabkan karakteristik sunk cost dari aktiva tetap, seperti tanah, gedung dan bangunan sehingga semakin tinggi jumlahnya maka akan semakin tinggi hutang yang dimiliki perusahaan. Struktur aktiva memiliki pengaruh yang positif terhadap kebijakan hutang perusahaan terutama bagi perusahaan yang memiliki ativa tetap dengan jumlah yang besar. Dengan kata lain bahwa aktiva tetap yang dimiliki perusahaan dapat dijadikan jaminan kepada pihak kreditor sehingga dengan hal tersebut maka perusahaan dapat memperoleh pinjaman yang dijadikan sumber dana bagi perusahaan. Hal tersebut konsisten dengan hasil penelitian yang dilakukan oleh Margaretha dan Asmariani (2009), Steven dan Lina (2011), Surya dan Rahayuningsih (2012), Susanto (2011), Yeniatie dan Destriana (2010) yang menyatakan bahwa struktur aktiva memiliki pengaruh terhadap kebijakan hutang.

\section{$\mathrm{H}_{3}$ : Struktur aktiva berpengaruh terhadap} kebijakan hutang.

\section{Pengaruh Ukuran Perusahaan terhadap Kebijakan Hutang}

Ukuran perusahaan adalah suatu skala yang dapat diklasifikasikan dalam besar dan kecilnya perusahaan dengan cara total aktiva, log size, nilai pasar saham dan stabilitas penjualan (Hol dan Wijst, 2006 dalam Susilawati, Agustina dan Tin, 2012). Besar kecilnya suatu perusahaan akan berpengaruh terhadap struktur modal, dengan kata lain semakin besar perusahaan maka akan semakin besar pula dana yang dibutuhkan perusahaan untuk melakukan investasi dan untuk menunjang kegiatan operasionalnya. Hubungan ukuran perusahaan dengan kebijakan hutang adalah jika semakin besar ukuran sebuah perusahaan maka kecenderungan menggunakan pendanaan eksternal semakin kecil, artinya perusahaan yang besar cenderung lebih kecil menggunakan hutang. Hal ini disebabkan karena perusahaan besar memiliki resiko kebangkrutan yang tinggi maka perusahaan besar lebih menyukai dengan cara mendanai operasional perusahaannya berusaha untuk menggunakan pendanaan internal dan lebih berhati-hati dalam menggunakan hutang. Hal tersebut konsisten dengan hasil penelitian yang dilakukan oleh Margaretha dan Asmariani (2009), Surya dan Rahayuningsih (2012), Susanto (2011) yang menyatakan bahwa ukuran perusahaan memiliki pengaruh terhadap kebijakan hutang.

\section{$\mathbf{H}_{4}$ : Ukuran Perusahaan berpengaruh} terhadap kebijakan hutang.

\section{Pengaruh Free Cash Flow terhadap Kebijakan Hutang}

Free cash flow is the amount of discretionary cash flow a company has. It can use this cashflow to purchase additional investements, retire its debt, purchase treasury shares, or 
simply add to its liquidity (Kieso, 2011:211212) Hubungan free cash flow dengan kebijakan hutang adalah perusahaan dengan free cash flow besar akan mempunyai level hutang yang tinggi, dan akan menurunkan agency cost free cash flow dan sebaliknya dengan perusahaan yang free cash flow rendah. Hal tersebut konsisten dengan hasil penelitian yang dilakukan oleh Indahningrum dan Handayani (2009), Susilawati, Agustina dan Tin (2012) yang menunjukkan bahwa free cash flow memiliki pengaruh terhadap kebijakan hutang.

$\mathbf{H}_{5}$ : Free cash flow berpengaruh terhadap kebijakan hutang.

\section{Pengaruh Profitabilitas terhadap Kebijakan Hutang}

Profitabilitas merupakan tingkat keuntungan bersih yang mampu dicapai perusahaan pada saat menjalankan operasionalnya (Susilawati, Agustina dan Tin, 2012). Apabila laba perusahaan tinggi, maka pendanaan dari sektor internal akan mencukupi untuk membiayai kebutuhan tersebut. Semakin tinggi profit yang diperoleh perusahaan maka akan semakin kecil penggunaan hutang dalam pendanaan perusahaan. Apabila kebutuhan dana perusahaan belum mencukupi, perusahaan dapat menggunakan hutang. Hal tersebut konsisten dengan penelitian yang dilakukan oleh Indahningrum dan Handayani (2009), Karinaputri dan Sofian (2012), Steven dan Lina (2011), Surya dan Rahayuningsih (2012), Susanto (2011), Susilawati, Agustina dan Tin (2012), Yeniatie dan Destriana (2010) menyatakan bahwa terdapat pengaruh antara profitabilitas terhadap kebijakan hutang.

\footnotetext{
$\mathrm{H}_{6}$ : Profitabilitas berpengaruh terhadap kebijakan hutang.

$\mathrm{H}_{7}$ : Struktur insider ownership, set peluang investasi, struktur aktiva, ukuran perusahaan, free cash flow, dan profitabilitas secara simultan berpengaruh terhadap kebijakan hutang.
}

\section{METODE PENELITIAN}

\section{Populasi dan Sampel}

Populasi dalam penelitian ini adalah 137 perusahaan manufaktur yang terdaftar di Bursa Efek Indonesia periode 2011-2013. Pemilihan sampel ditentukan secara sampling purposive. Purposive sampling adalah teknik penentuan sampel dengan pertimbangan tertentu. Di mana sampel yang diambil ditentukan sendiri oleh peneliti dan dengan kriteria yang ditentukan (Sugiyono, 2008:68). Sampel yang diambil dalam penelitian ini adalah 34 perusahaan manufaktur yang terdaftar di Bursa Efek Indonesia (BEI). Adapun kriteria yang digunakan dalam penelitian ini adalah sebagai berikut:

a. Perusahaan manufaktur yang tercatat sebagai emiten pada periode 2011, 2012, dan 2013 secara kontinyu (tidak pernah delisting).

b. Perusahaan manufaktur yang berturut-turut 2011-2013 tutup buku pada tanggal 31 Desember.

c. Perusahaan yang menyajikan laporan keuangan secara lengkap dan melaporkannya dalam mata uang Rupiah.

d. Perusahaan manufaktur memiliki data yang terkait dengan variabel - variabel yang digunakan dalam penelitian.

\section{Operasionalisasi dan Pengukuran Variabel}

Operasional variabel adalah suatu cara untuk mengukur konsep sehhingga terdapat variabel-variabel yang saling mempengaruhi dan dipengaruhi. Variabel-variabel tersebut pada penelitian ini adalah:

a. Kebijakan Hutang

Variabel dependen ini menggambarkan porsi hutang jangka panjang yang dimiliki perusahaan terhadap keseluruhan struktur modal. Variabel ini dihitung dengan rumus yang digunakan dalam penelitian Indahningrum dan Handayani ( 2009 ). 


DER $=\frac{\text { Total hutang jangka panjang }}{\text { Total ekuitas akhir tahun }}$

b. Struktur Kepemilikan Manajerial (Insider Ownership Structure)

Kepemilikan manajerial atau insider adalah tingkat kepemilikan saham pihak manajemen yang secara aktif ikut dalam pengambilan keputusan (Wahidahwati, 2002). Variabel ini diukur dengan rumus yang digunakan oleh Masdupi (2005) dalam Indahningrum dan Handayani (2009).

Struktur Insider Ownership= kepemilikan saham manajerial

Jumlah saham yang beredar

c. Set Peluang Investasi (A Set Investment of Opportunity)

Set peluang investasi adalah tersediaanya alternatif investasi di masa datang bagi perusahaan. Teori investment opportunity set berkaitan dengan keputusan pendanaan yang telah dilakukan perusahaan terdiri dari keputusan pendanaan jangka pendek, menengah dan jangka panjang (Susanto, 2011). Variabel ini dihitung dengan rumus seperti yang digunakan dalam penelitian Susanto (2011).

Set Peluang Investasi = Laba per lembar saham

Harga jual saham

\section{d. Struktur Aktiva}

Struktur aktiva adalah penetuan seberapa besar alokasi dana untuk masingmasing komponen aktiva, baik dalam aktiva lancar maupun aktiva tetap (Mamduh, 2004) dalam (Susilawati, Agustina dan Tin, 2012).. Variabel ini dihitung dengan rumus seperti yang digunakan dalam penelitian Abror, J (2008) dalam Margaretha dan Asmariani (2009).

$$
\text { Struktur Aktiva }=\frac{\text { Aktiva Tetap }}{\text { Total Aktiva }}
$$

\section{e. Ukuran Perusahaan}

Ukuran perusahaan didefinisikan sebagai salah satu variabel independen di mana menggunakan total asset sebagai wujud dari ukuran perusahaan. Diukur berdasarkan total asset. Total aktiva yang dimiliki oleh setiap perusahaan sampel digunakan sebagai tolok ukur skala perusahaan (Susanto 2011). Variabel ini dihitung dengan rumus seperti yang digunakan dalam penelitian Susanto (2011).

$$
S I Z E=\log (\text { Total Asset })
$$

\section{f. Free Cash Flow}

Menurut Kieso (2011:211-212) free cash flow is the amount of discretionary cash flow a company has. It can use this cash flow to purchase additional investements, retire its debt, purchase treasury shares, or simply add to its liquidity. Variabel ini dihitung dengan rumus seperti yang digunakan dalam penelitian Jones dan Sharma dalam Arfan dan Maywindlan (2013).

FCF it $=\frac{\text { AKO it }+ \text { AKI it }}{\text { Total Aktiva }}$

$\mathrm{AKO}$ it $=$ aliran kas operasi perusahaan $\mathrm{i}$ pada tahun $\mathrm{t}$

AKI it $=$ aliran kas investasi perusahaan $\mathrm{i}$ pada tahun $\mathrm{t}$

g. Profitabilitas

Profitabilitas merupakan tingkat keuntungan bersih yang mampu diraih oleh perusahaan pada saat menjalankan operasionalnya (Susilawati, Agustina dan Tin, 2012). Profitabilitas diukur dari EAT dibagi dengan total asset. Variabel ini dihitung dengan rumus seperti yang digunakan dalam Keiso (2011:223). 


$$
\text { ROA }=\frac{\text { EAT }}{\text { Total Asset }} \times 100 \%
$$

\section{Teknik Analisis Data}

Teknik analisis data dimulai dari Statistik Deskriptif (nilai rata-rata, standar deviasi, maksimum dan minimum) uji kualitas data (uji validitas dan reliabilitas), ${ }^{{ }_{11}} \mathrm{Uji}$ Normalitas Data, uji Korelasi (berganda dan parsial), Uji Regresi Berganda, Uji Asumsi Klasik Regresi, dan Pengujian Hipotesis (Uji Signifikansi Korelasi Berganda, Uji Signifikansi Korelasi Parsial, Uji Signifikansi Regresi Berganda, Uji Signifikansi Regresi Parsial dan Koefisien Determinasi).

\section{HASIL PENELITIAN DAN PEMBAHASAN}

a. Uji Signifikansi Regresi Parameter Individual (Uji Statistik t)

Tabel 1

\section{Hasil Uji Signifikansi Regresi Parsial} Coefficients $^{\mathrm{a}}$

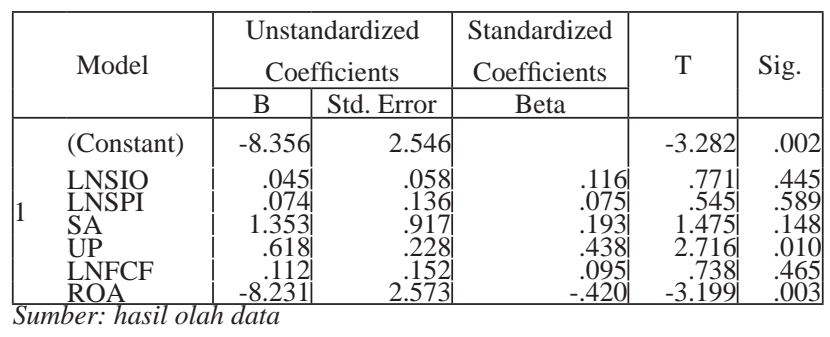

a. Dependent Variable: LNDER

Dengan mengacu pada persamaan regresi yang diperoleh maka model regresi tersebut dapat diinterpretasikan sebagai berikut :

Dari hasil di atas dapat diketahui bahwa untuk pengujian hipotesis pertama $(\mathrm{H} 1)$ dengan variabel struktur insider ownership dengan konstan $\alpha$ sebesar -8,356 menyatakan bahwa jika struktur insider ownership konstan 0, maka kebijakan hutang (Y) sebesar -8,356. Koefisien $\beta$ sebesar positif 0,045 menunjukan bahwa jika struktur insider ownership mengalami kenaikan
1 kali maka akan terjadi kenaikan jumlah struktur insider ownership sebanyak 0,045 kali dan sebaliknya jika struktur insider ownership mengalami penurunan maka kebijakan hutang akan mengalami penurunan. P-value untuk variabel struktur insider ownership sebesar 0.445. mengingat $P$-value tersebut lebih besar dari $\alpha$ (5\%) maka dapat disimpulkan bahwa struktur insider ownership tidak berpengaruh terhadap kebijakan hutang. Yang berarti H1 ditolak.

Untuk pengujian hipotesis kedua (H2) dengan variabel set peluang investasi dengan konstan $\alpha$ sebesar -8,356 menyatakan bahwa jika set peluang investasi konstan 0, maka kebijakan hutang sebesar -8,356. Koefisien $\beta$ sebesar positif 0,074 menunjukan bahwa jika set peluang investasi mengalami kenaikan 1 kali maka akan terjadi kenaikan jumlah kebijakan hutangsebanyak 0,074 kali dan sebaliknya jika set peluang investasi mengalami penurunan maka kebijakan hutang akan mengalami penurunan. $P$-value untuk variabel set peluang investasi sebesar 0.589 . mengingat $P$-value tersebut lebih besar dari $\alpha(5 \%)$ maka dapat disimpulkan bahwa set peluang investasi tidak berpengaruh terhadap kebijakan hutang. Yang berarti H2 ditolak.

Untuk pengujian hipotesis ketiga (H3) dengan variabel struktur aktiva dengan konstan $\alpha$ sebesar -8,356 menyatakan bahwa jika nilai struktur aktiva konstan 0, maka kebijakan hutang sebesar -8,356. Koefisien $\beta$ sebesar positif 1,353 menunjukan bahwa jika struktur aktiva mengalami kenaikan 1 kali maka akan terjadi kenaikan jumlah kebijakan hutangsebanyak 1.353 kali dan sebaliknya jika struktur aktiva mengalami penurunan maka kebijakan hutang akan mengalami penurunan. P-value untuk variabel struktur aktiva sebesar 0,148 . mengingat $P$-value tersebut lebih besar dari $\alpha(5 \%)$ maka dapat disimpulkan bahwa struktur aktiva tidak berpengaruh terhadap kebijakan hutang. Yang berarti $\mathbf{H 3}$ ditolak. 
Untuk pengujian hipotesis keempat (H4) dengan variabel ukuran perusahaan dengan konstan $\alpha$ sebesar -8,356 menyatakan bahwa jika nilai ukuran perusahaankonstan 0 , maka kebijakan hutang sebesar -8,356. Koefisien $\beta$ sebesar positif 0,618 menunjukan bahwa jika ukuran perusahaan mengalami kenaikan 1 kali maka akan terjadi kenaikan jumlah kebijakan hutangsebanyak 1.353 kali dan sebaliknya jika ukuran perusahaan mengalami penurunan maka kebijakan hutang akan mengalami penurunan. $P$-value untuk variabel struktur aktiva sebesar 0,010 . mengingat $P$-value tersebut lebih kecil dari $\alpha(5 \%)$ maka dapat disimpulkan bahwa ukuran perusahaan berpengaruh terhadap kebijakan hutang. Yang berarti H4 diterima dan terbukti.

Untuk pengujian hipotesis kelima (H5) dengan variabel free cash flow dengan konstan a sebesar -8,356 menyatakan bahwa jika nilai free cash flow konstan 0, maka kebijakan hutang sebesar -8,356. Koefisien $\beta$ sebesar positif 0,112 menunjukan bahwa jika free cash flow mengalami kenaikan 1 kali maka akan terjadi kenaikan jumlah kebijakan hutangsebanyak 0,112 kali dan sebaliknya jika free cash flow mengalami penurunan maka kebijakan hutang akan mengalami penurunan. P-value untuk variabel free cash flow sebesar 0,465. mengingat $P$-value tersebut lebih besar dari $\alpha(5 \%)$ maka dapat disimpulkan bahwa free cash flow tidak berpengaruh terhadap kebijakan hutang. Yang berarti $\mathrm{H5}$ ditolak.

Untuk pengujian hipotesis keenam (H6) dengan variabel profitabilitas dengan konstan $\alpha$ sebesar -8,356 menyatakan bahwa jika nilai profitabilitas konstan 0, maka kebijakan hutang sebesar -8,356. Koefisien $\beta$ sebesar negatif 8,231 menunjukan bahwa jika profitabilitas mengalami kenaikan 1 kali maka akan terjadi penurunan jumlah kebijakan hutang sebanyak 8,231 kali dan sebaliknya jika profitabilitas mengalami penurunan maka kebijakan hutang akan mengalami kenaikan. $P$-value untuk variabel profitabilitas sebesar 0,003 . mengingat $P$-value tersebut lebih kecil dari $\alpha(5 \%)$ maka dapat disimpulkan bahwa profitabilitas berpengaruh terhadap kebijakan hutang. Yang berarti H6 diterima dan terbukti.

$$
\begin{gathered}
\mathrm{Y}=-8,356+0,045+0,074+1,353+0,618+ \\
0,112-8,231
\end{gathered}
$$

\section{Uji Signifikansi Simultan (Uji Statistik F)}

Analisis ini digunakan untuk mengetahui besarnya pengaruh struktur insider ownership, set peluang investasi, struktur aktiva, ukuran perusahaan, free cash flow dan profitabilitas terhadap kebijakan hutang secara simultan. Dari tabel 4.9 dibawah dapat diketahui bahwa $p$-value untuk variabel struktur insider ownership, set peluang investasi, struktur aktiva, ukuran perusahaan, free cash flow dan profitabilitas adalah sebesar 0,01 yang lebih kecil dari $\alpha$ (5\%) maka dapat disimpulkan bahwa struktur insider ownership, set peluang investasi, struktur aktiva, ukuran perusahaan, free cash flow dan profitabilitas berpengaruh terhadap kebijakan hutang yang berarti $\mathbf{H 7}$ diterima atau terbukti.

Tabel 2

Uji Simultan (Uji Statistik F)

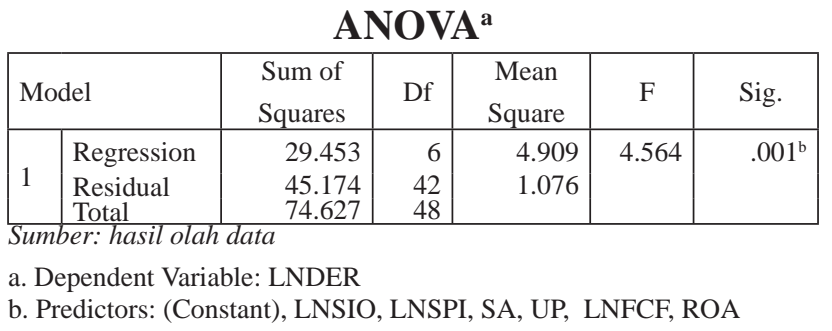

\section{Koefisien Determinasi $\left(\mathbf{R}^{2}\right)$}

Uji koefisien determinasi digunakan untuk mengukur seberapa jauh kemampuan model dalam menerangkan variasi variabel-variabel dependen. Hasil dari koefisien determinasi dapat dilihat pada tabel 3 di bawah ini: 


\section{Tabel 3}

Koefisien Determinasi $\left(\mathbf{R}^{2}\right)$ Model Summary ${ }^{b}$

\begin{tabular}{|l|r|r|r|r|}
\hline Model & R & R Square & $\begin{array}{c}\text { Adjusted R } \\
\text { Square }\end{array}$ & $\begin{array}{c}\text { Std. Error of the } \\
\text { Estimate }\end{array}$ \\
\hline 1 & $.628^{\mathrm{a}}$ & .395 & .308 & 1.037101 \\
\hline
\end{tabular}

a. Predictors: (Constant), LNSIO, LNSPI, SA, UP, LNFCF, ROA b. Dependent Variable: LNDER

Dari tabel 3 di atas menunjukan bahwa Adjusted R Square adalah sebesar 30,8 \%. Hal ini menunjukan bahwa hanya 30,8 \% variabel kebijakan hutang dapat dijelaskan oleh variabel independen yaitu struktur insider ownership, set peluang investasi, struktur aktiva, ukuran perusahaan, free cash flow dan profitabilitas. Sedangkan sisanya sebesar 69,2 \% (100\% - 30,8 $\%$ ) dijelaskan oleh faktor-faktor lain diluar model yang dianalisis.

\section{KESIMPULAN DAN SARAN}

\section{KESIMPULAN}

Berdasarkan hasil dan analisis sebelumnya maka temuan dalam penelitian ini adalah:

1. Secara parsial struktur insider ownership, set peluang investasi, dan free cash flow tidak mempunyai pengaruh terhadap Kebijakan Hutang. Namun sebaliknya, ukuran perusahaan dan profitabilitas secara parsial mempunyai pengaruh terhadap Kebijakan Hutang.

2. Secara simultan, Struktur Kepemilikan Manajerial (Insider Ownership Structure), Set Peluang Investasi, Struktur Aktiva, Ukuran Perusahaan, Free Cash Flow, dan Profitabilitas mempunyai pengaruh terhadap Kebijakan Hutang.

\section{SARAN}

Saran dalam penelitian ini antara lain :

1. Variabel Independen yang dipakai dalam penelitian masih terbatas, hanya mengkaji Struktur Insider Ownership ,Set Peluang
Investasi, Struktur Aktiva, Ukuran Perusahaan, Free Cash Flow, Profitabilitas saja. Nilai adjusted $\mathrm{R}^{2}$ yang hanya $30,8 \%$ menunjukkan bahwa masih kecilnya pengaruh variabelvariabel yang dikaji dalam penelitian ini terhadap kebijakan hutang perusahaan dibandingkan variabel-variabel lain, misalnya seperti kepemilikan institusional, kebijakan deviden, pertumbuhan perusahaan, firm age, financial leverage dan lain-lain. Oleh karena itu, peneliti selanjutnya sebaiknya menambahkan variabel lain sebagaimana dikemukakan di atas.

2. Data dalam penelitian ini hanya menggunakan tahun pengamatan selama 3 tahun (20112013) saja. Jadi walaupun periode pengamatan sampai dengan Januari 2014 dan sudah memasuki tahun 2014, namun laporan keuangan tahunan untuk 2014 baru terpublikasi pada 31 maret 2015. Peneliti selanjutnya sebaiknya menanbah tahun pengamatan berikutnya khususnya tahun 2014.

3. Hasil yang diperoleh dari penelitian ini dapat dijadikan bahan pertimbangan perusahaan dalam membuat kebijakan penambahan modal khususnya melalui hutang dengan lebih mencermati keadaan perekonomian dan keadaan perusahaannya.

4. Hasil penelitian ini dapat juga digunakan oleh investor yang akan melakukan investasi di perusahaan yang listing di BEI dengan mencermati kebijakan hutang yang dilakukan perusahaan.

\section{DAFTAR PUSTAKA}

Arfan, M. dan T. Maywindlan. 2013. Pengaruh Arus Kas Bebas, Collateralizable Assets dan Kebijakan Utang Terhadap Kebijakan Deviden Pada Perusahaan Yang Terdaftar Di Jakarta Islamic Index. Jurnal telaah dan Riset Akuntansi, 6(2): 194-208 
.Ghozali, I. 2011. Aplikasi Analisis Multivariate Dengan program SPSS 19. Semarang: Badan Penerbit Universitas Diponogoro.

Ikhsan, A. dan H. B. Suprasto. 2008. Teori Akuntansi dan Riset Multiparadigma. Yogyakarta: Penerbit Graha Ilmu.

Indahningrum, R. P. dan R. Handayani. 2002. Pengaruh Kepemilikan Manajerial, Kepemilikan Institusional, Deviden, Pertumbuhan Perusahaan, Free Cash Flow dan Profitabilitas Terhadap Kebijakan Hutang Perusahaan. Jurnal Bisnis dan Akuntansi, 11(3): 189-207.

Keiso, D. E. , J. J. Weygandt. dan T. D. Warfield. 2011. Intermediate Accounting IFRS Edition. United State: Wiley.

Karinaputri, N. dan S. Sofian. 2012. Analisis Pengaruh Kepemilikan Insitusional, Kebijakan Deviden, Profitabilitas Dan Pertumbuhan Perusahaan Terhadap Kebijakan Hutang (Studi Pada Perusahaan Manufaktur Yang Terdaftar Di Bursa Efek Indonesia Tahun 20082010). Journal Of Management, 1(1): 1-9.

Margaretha, F. dan A. Asmariani. 2009. Faktor-Faktor Agency Theory Yang Mempengaruhi Hutang. Media Riset Bisnis dan Manajemen, 9(1): 1-20.

Steven dan Lina. 2011. Faktor-Faktor Yang Mempengaruhi Kebijakan Hutang Perusahaan Manufaktur. Jurnal Bisnis dan Akuntansi, 13(1): 136-181.
Sugiyono. 2008. Statistik untuk Penelitian. Bandung: Penerbit ALFABETA BANDUNG.

Surya, D. dan D. A. Rahayuningsih. 2012. FaktorFaktor Yang Mempengaruhi Kebijakan Hutang Perusahaan Non Keuangan Yang Terdaftar Dalam Bursa Efek Indonesia. Jurnal Bisnis dan Akuntansi, 14(3): 213-225.

Susanto, Y. K. 2011. Kepemilikan Saham, Kebijakan Deviden, Karakteristik Perusahaan, Resiko Sistimatik, Set Peluang Investasi Dan Kebijakan Hutang. Jurnal Bisnis dan Akuntansi, 13(3): 195-210.

Susilawati, C. D. K., L. Agustina dan S. Tin. 2012. Faktor-Faktor Yang Memengaruhi Kebijakan Hutang Perusahaan Manufaktur Yang Terdaftar Di Bursa Efek Indonesia. Jurnal Keuangan dan Perbankan, 16(2): 178-187.

Wahidahwati. 2002. Pengaruh Kepemilikan Manajerial dan Kepemilikan institusional pada Kebijakan Hutang Perusahaan: Sebuah Prespektif Theory Agency. Media Riset Akuntansi Indonesia, 5(1): 1-16.

Yeniatie dan N. Destriana. 2010. Faktor-Faktor Yang Mempengaruhi Kebijakan Hutang Perusahaan Non Keuangan Yang Terdaftar Dalam Bursa Efek Indonesia. Jurnal Bisnis dan Akuntansi, 12(1): 1-16. 
Lampiran

Tabel 4.3

Staistik Deskriptif

Statistics

\begin{tabular}{|l|c|c|c|c|c|c|c|c|}
\hline \multirow{2}{*}{$\mathrm{N}$} & Valid & DER & SIO & SPI & SA & UP & FCF & ROA \\
\cline { 2 - 8 } & 102 & 102 & 102 & 102 & 102 & 102 & 102 \\
\cline { 2 - 8 } Missing & 0 & 0 & 0 & 0 & 0 & 0 & 0 \\
\hline Mean & .599 & .0391 & .0621 & .362 & 12.259 & .008 & .059 \\
\hline Median & .222 & .0042 & .0701 & .305 & 12.069 & .014 & .05357 \\
\hline $\begin{array}{l}\text { Std. } \\
\text { Deviation }\end{array}$ & 1.678 & .0598 & .1673 & .194 & .814 & .127 & .06891 \\
\hline
\end{tabular}

Tabel 4.4

Uji Normalitas Data

\section{One-Sample Kolmogorov-Smirnov Test}

\begin{tabular}{|c|c|c|c|c|c|c|c|c|}
\hline \multirow{2}{*}{\multicolumn{2}{|c|}{$\mathrm{N}$}} & DER & SIO & SPI & SA & UP & FCF & ROA \\
\hline & & 102 & 102 & 102 & 102 & 102 & 102 & 102 \\
\hline \multirow{2}{*}{$\begin{array}{l}\text { Normal } \\
\text { Parameters }{ }^{\mathrm{a}, \mathrm{b}}\end{array}$} & Mean & .599 & .039 & .062 & .362 & 12.259 & .008 & .059 \\
\hline & $\begin{array}{l}\text { Std. } \\
\text { Deviation }\end{array}$ & 1.678 & .059 & .167 & .194 & .814 & .127 & .068 \\
\hline \multirow{3}{*}{$\begin{array}{l}\text { Most } \\
\text { Extreme } \\
\text { Differences }\end{array}$} & Absolute & .364 & .256 & .252 & .127 & .112 & .136 & .063 \\
\hline & Positive & .338 & .239 & .113 & .127 & .112 & .136 & .063 \\
\hline & Negative & -.364 & -.256 & -.252 & -.053 & -.067 & -.115 & -.058 \\
\hline \multicolumn{2}{|c|}{ Kolmogorov-Smirnov Z } & 3.680 & 2.588 & 2.550 & 1.278 & 1.130 & 1.374 & .634 \\
\hline \multicolumn{2}{|c|}{ Asymp. Sig. (2-tailed) } & .000 & .000 & .000 & .076 & .155 & .046 & .817 \\
\hline
\end{tabular}

Tabel 4.5

\section{One-Sample Kolmogorov-Smirnov Test}

\begin{tabular}{|c|c|c|c|c|c|c|c|c|}
\hline & LNDER & LNSIO & \begin{tabular}{|l|l} 
LNSPI \\
\end{tabular} & SA & UP & LNFCF & ROA \\
\hline \multicolumn{2}{|l|}{ N } & $\begin{array}{r}102 \\
-1585\end{array}$ & $\begin{array}{r}102 \\
-5383\end{array}$ & $\begin{array}{r}90 \\
-2562\end{array}$ & $\begin{array}{r}102 \\
362\end{array}$ & $\begin{array}{r}102 \\
12.259\end{array}$ & $\begin{array}{r}57 \\
-3002\end{array}$ & $\begin{array}{r}10 \\
.05\end{array}$ \\
\hline vormal & & & & & & & & \\
\hline Parameters ${ }^{\mathrm{a}, \mathrm{b}}$ & & 1.324 & 2.898 & 1.079 & .194 & .814 & 1.08 & \\
\hline reme & & & $\begin{array}{l}.135 \\
.083\end{array}$ & $\begin{array}{l}.140 \\
.096\end{array}$ & $\begin{array}{l}.127 \\
.127\end{array}$ & $\begin{array}{l}.112 \\
.112\end{array}$ & $\begin{array}{l}.085 \\
.067\end{array}$ & .06 \\
\hline & & -.047 & -.1 & & -.053 & -.067 & -.085 & -.0 \\
\hline$-S n$ & mirne & .642 & 1.360 & 1.332 & 1.278 & 1.130 & .645 & .634 \\
\hline Asymp. Sig. (2- & -tailed) & .805 & .049 & .058 & .076 & .155 & .800 & .81 \\
\hline
\end{tabular}

a. Test distribution is Normal.

b. Calculated from data.
Uji Normalitas Data Setelah

Transformasi

Histogram

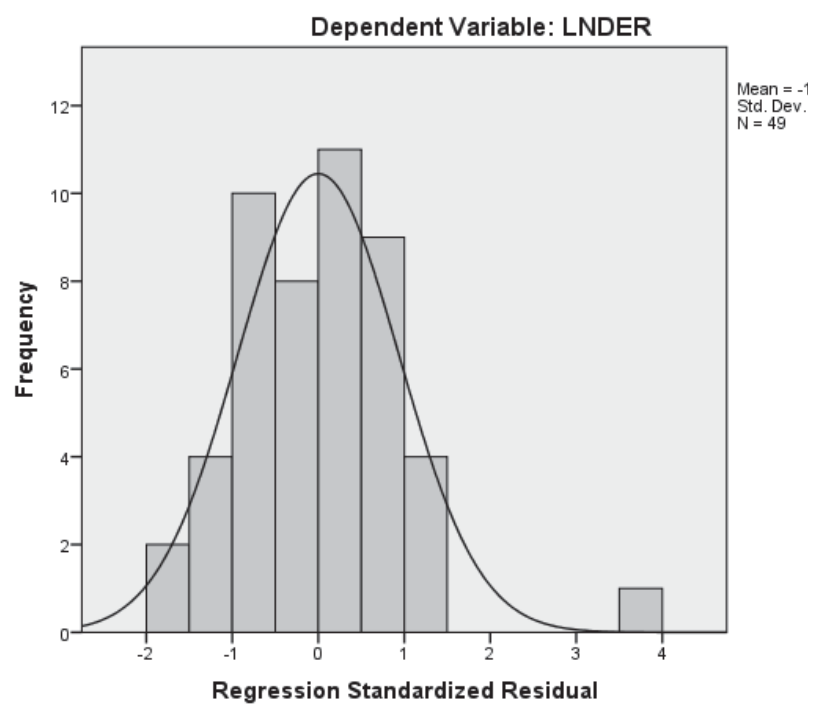

Normal P-P Plot of Regression Standardized Residual

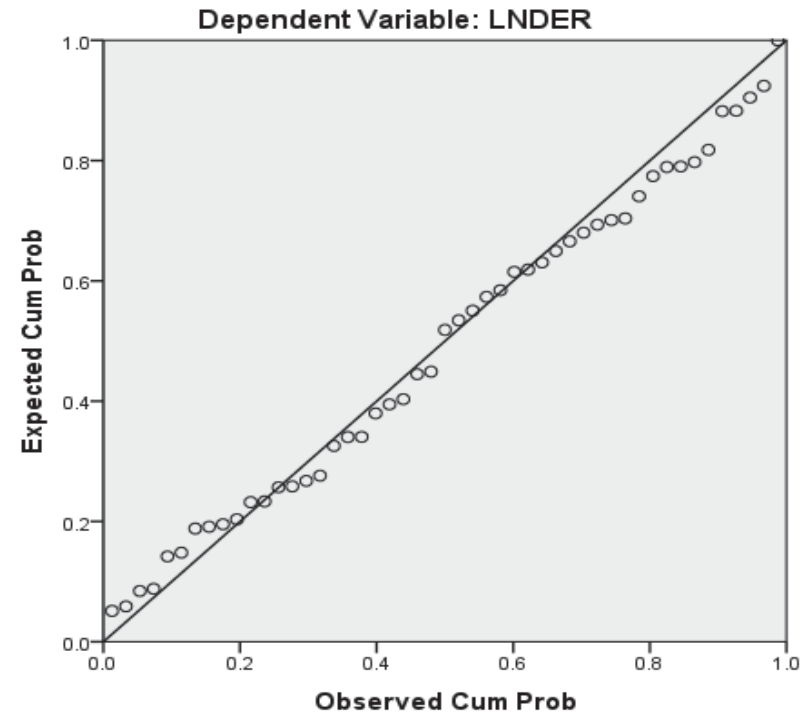


Tabel 4.6

Uji Multikolonieritas

Coefficients $^{\mathrm{a}}$

\begin{tabular}{|c|c|c|c|c|c|c|c|c|}
\hline & \multirow[t]{2}{*}{ Model } & \multicolumn{2}{|c|}{$\begin{array}{l}\text { Unstandardized } \\
\text { Coefficients }\end{array}$} & \multirow{2}{*}{$\begin{array}{c}\text { Standardized } \\
\text { Coefficients }\end{array}$} & \multirow[t]{2}{*}{$\mathrm{t}$} & \multirow[t]{2}{*}{ Sig. } & \multicolumn{2}{|c|}{ Collinearity Statistics } \\
\hline & & B & Std. Error & & & & \begin{tabular}{|l|} 
Tolerance \\
\end{tabular} & VIF \\
\hline \multirow{7}{*}{1} & (Constant) & -8.356 & 2.546 & & -3.282 & .002 & & \\
\hline & LNSIO & .045 & .058 & .116 & .771 & .445 & .638 & 1.567 \\
\hline & LNSPI & .074 & .136 & .075 & .545 & .589 & .753 & 1.328 \\
\hline & SA & 1.353 & .917 & .193 & 1.475 & .148 & .840 & 1.190 \\
\hline & UP & .618 & .228 & .438 & 2.716 & .010 & .554 & 1.804 \\
\hline & LNFCF & .112 & .152 & .095 & .738 & .465 & .865 & 1.156 \\
\hline & ROA & -8.231 & 2.573 & -.420 & -3.199 & .003 & .837 & 1.195 \\
\hline
\end{tabular}

Tabel 4.7

Uji Autokorelasi

Model Summary ${ }^{b}$

\begin{tabular}{l|c|r|r|r|l|}
\hline Model & R & R Square & $\begin{array}{c}\text { Adjusted R } \\
\text { Square }\end{array}$ & $\begin{array}{c}\text { Std. Error of the } \\
\text { Estimate }\end{array}$ & \multicolumn{2}{|c|}{ Durbin-Watson } \\
\hline 1 & $.628^{\mathrm{a}}$ & .395 & .308 & 1.037101 & 1.965 \\
\hline
\end{tabular}

Scatterplot

Dependent Variable: LNDER

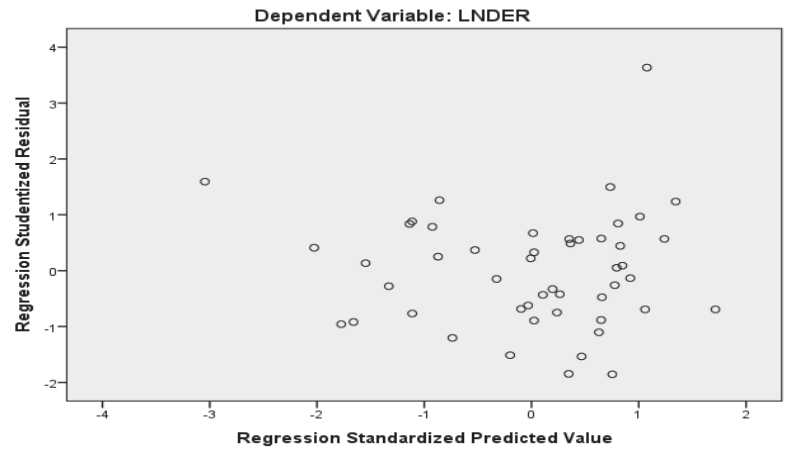

Uji Signifikansi Regresi Parameter Individual

(Uji Statistik t)

Tabel 4.8

Coefficients $^{\mathrm{a}}$

\begin{tabular}{|c|c|c|c|c|c|}
\hline \multirow{3}{*}{ Model } & \multirow{2}{*}{\multicolumn{2}{|c|}{$\begin{array}{l}\text { Unstandardized } \\
\text { Coefficients }\end{array}$}} & \multirow{3}{*}{\begin{tabular}{|c|}
$\begin{array}{c}\text { Standardized } \\
\text { Coefficients }\end{array}$ \\
Beta \\
\end{tabular}} & \multirow{3}{*}{$\mathrm{T}$} & \multirow{3}{*}{ Sig. } \\
\hline & & & & & \\
\hline & B & Std. Error & & & \\
\hline (Constant) & -8.356 & 2.546 & & -3.282 & .002 \\
\hline LNSIO & .045 & .058 & .116 & .771 & .445 \\
\hline LNSPI & .074 & .136 & .075 & .545 & .589 \\
\hline SA & 1.353 & .917 & .193 & 1.475 & .148 \\
\hline UP & .618 & .228 & .438 & 2.716 & .010 \\
\hline LNFCF & .112 & .152 & .095 & .738 & .465 \\
\hline ROA & -8.231 & 2.573 & -.420 & -3.199 & .003 \\
\hline
\end{tabular}

Tabel 4.9

Uji Simultan (Uji Statistik F)

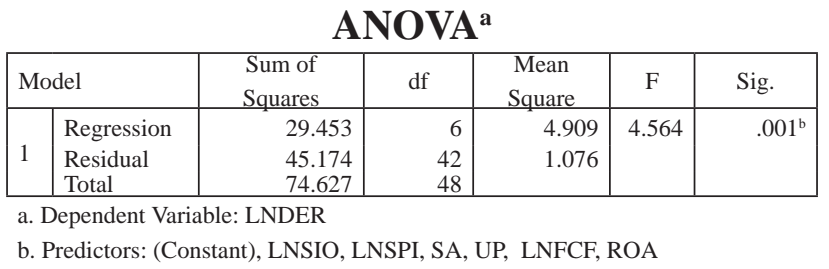

Tabel 4.10

Koefisien Determinasi $\left(\mathrm{R}^{2}\right)$ Model Summary ${ }^{b}$

\begin{tabular}{|l|r|r|r|c|}
\hline Model & \multicolumn{1}{|c|}{$\mathrm{R}$} & R Square & Adjusted R Square & $\begin{array}{c}\text { Std. Error of the } \\
\text { Estimate }\end{array}$ \\
\hline 1 & $.628^{\mathrm{a}}$ & .395 & .308 & 1.037101 \\
\hline
\end{tabular}

a. Predictors: (Constant), LNSIO, LNSPI, SA, UP, LNFCF, ROA

b. Dependent Variable: LNDER 